\title{
Biomechanical Comparison of Prototype of a Novel Intramedullary Injectable Bioresorbable Polymer-Bioresorbable Balloon Osteosynthesis and a Volar Locking Plate for Treatment of Distal Radius Fractures
}

\author{
Adam Zysk ${ }^{1}$, Gladius Lewis ${ }^{1 *}$, Daniel Taxier ${ }^{2}$, John Rose $^{2}$ \\ ${ }^{1}$ Department of Mechanical Engineering, the University of Memphis, Memphis, TN, USA \\ ${ }^{2}$ Smith \& Nephew, Memphis, TN, USA \\ Email: *glewis@memphis.edu
}

How to cite this paper: Zysk, A., Lewis, G. Taxier, D. and Rose, J. (2017) Biomechanical Comparison of Prototype of a Novel Intramedullary Injectable Bioresorbable Polymer-Bioresorbable Balloon Osteosynthesis and a Volar Locking Plate for Treatment of Distal Radius Fractures. World Journal of Engineering and Technology, 5, 309-323.

https://doi.org/10.4236/wjet.2017.52025

Received: March 17, 2017

Accepted: May 24, 2017

Published: May 27, 2017

Copyright (๑) 2017 by authors and Scientific Research Publishing Inc. This work is licensed under the Creative Commons Attribution International License (CC BY 4.0).

http://creativecommons.org/licenses/by/4.0/

(c) (i) Open Access

\begin{abstract}
Background: There is a large assortment of modalities for the surgical treatment/management of distal radius fractures (DRFs), where the most widely used is the fixed-angle volar plating (VLP) system, which, sometimes, is referred to as the "surgical modality of choice". While outcomes with each modality are usually good to excellent, each has its share of shortcomings and complications. Thus, there is scope for improvements to existing modalities and/or introduction of new ones. Study Purpose: We introduce a novel modality, namely, the prototype of an intramedullary injectable bioresorbable polymer-bioresorbable balloon osteosynthesis (IPBO) system, and investigated its plausibility. Experimental Procedures: The biomechanical performance of a construct comprising a synthetic distal radius (fourth-generation Sawbones ${ }^{\circ}$ ) on which a simulated fracture was created (4-mm wide osteotomy positioned $25 \mathrm{~mm}$ from the most distal end of the radius) and fixated with a placement of the IPBO system (SIPBO Construct) was compared to that when the fixation was with an approved Ti-6Al-4V alloy VLP system (SVLP Construct), under a clinically-relevant compressive loading protocol. Performance involved determination of quantitative parameters of the construct (initial longitudinal stiffness (ICLS), final longitudinal stiffness (FCLS), and load-to-failure $\left(\mathrm{P}_{\mathrm{f}}\right)$ ) and observation and recording of features of the construct at the fracture point. We also determined the quantitative parameters for the intact synthetic distal radius (control). Results: For each of the quantitative parameters, the range of values for SIPBO Construct was within that for SVLP Construct, suggesting that the IPBO System is a plausible modality. Also, for SIPBO Construct, failure occurred within the polymer zone, whereas, for SVLP Con-
\end{abstract}


struct, some failure features were fracture of the cortical wall and of the dorsal proximal fragments. Conclusion: The findings suggest that the IPBO system is plausible. As such, it merits further study; for example, determination of the influence of fracture gap fill ratio (defined as the proportion of the fracture gap that is filled by the expanding balloon as the polymer is injected into the balloon) on a large collection of quantitative biomechanical parameters.

\section{Keywords}

Distal Radius Fractures, Volar Locking Plate, Injectable Bioresorbable Polymer, Biomechanical Tests

\section{Introduction}

Distal radius fractures (DRFs) are, undoubtedly, one of the most common fractures not only of the upper extremity but, also, of the whole skeletal system; for example, in the United States, they account for $-20 \%$ of cases presented at emergency medicine departments [1]. The incidence is the highest in the pediatric and osteoporotic elderly populations [2] [3]. Treatment/management modalities for DRFs may be divided into non-surgical (or conservative) and surgical types. Among the former, the most frequently used is cast immobilization, while, in the latter category, there are myriad options, such as percutaneous fixation via Kirschner wires, fixed-angle volar locking plate (VLP) system (comprising a plate and screws or pegs), fixed-angle dorsal locking plate system, intramedullary nailing, the photodynamic bone stabilization system, an expandable intramedullary cage with fragment-specific screw fixation, and a threaded pin device [3]-[9]. The most widely used modality is a VLP system [10] to the extent that some refer to it as the "treatment of choice" [11] [12]. There is a large volume of literature on clinical performance (functional scores and radiological outcomes) of many modalities, either on their own or in comparison with one or more of others [13]-[19]. This has led to identification and discussion of shortcomings and complications of many modalities [17]. For example, for a VLP system, a) its shortcomings include high possibility for prominence if applied distally and possibility for irritation of tendon(s) [14]; and b) among its complications are carpal tunnel syndrome, peripheral nerve palsy, extensor tenosynovitis, and rupture of tendon(s) [17] [19]. Thus, there is scope for modifications to current modalities and/or introduction of new ones. In this regard, we have a developed the prototype of a novel modality that utilizes an injectable bioresorbable polymer balloon and intramedullary placement; that is, a prototype of an intramedullary injectable bioresorbable polymer-bioresorbable balloon osteosynthesis (IPBO) system.

The purpose of the present study was to investigate the plausibility of the IPBO system. This was done by comparing the biomechanical performance of a construct comprising a synthetic distal radius on which a simulated fracture was created and then fixated using the IPBO system (SIPBO Construct) to that of a 
construct on which the simulated fracture was fixated using an approved Ti$6 \mathrm{Al}-4 \mathrm{~V}$ alloy VLP system (SVLP Construct). For this purpose, quantitative parameters of the construct (initial stiffness (stiffness computed over the initial linear section of the load (P)-versus-displacement $(\Delta)$ curve) (ICLS)), final stiffness (stiffness computed from the final linear section of the P- $\Delta$ curve) (FCLS), and load-to-failure $\left(\mathrm{P}_{\mathrm{f}}\right)$ ) were determined and features seen in the construct at its fracture point were observed and recorded. As control, ICLS, FCLS, and $\mathrm{P}_{\mathrm{f}}$ of intact Sawbones were obtained. The constructs and intact Sawbones were each subjected to a clinically-relevant compressive loading protocol.

\section{Materials and Experimental Procedures}

\subsection{Preparation of Intact Distal Radius}

The tests were conducted using fourth-generation composite radius bone (Model 3407; Sawbones; Pacific Research Laboratories, Vashon, WA) on which the radial aspect was cut off, thus yielding an effective length of $11 \mathrm{~cm}$ (Figure 1 (a)).

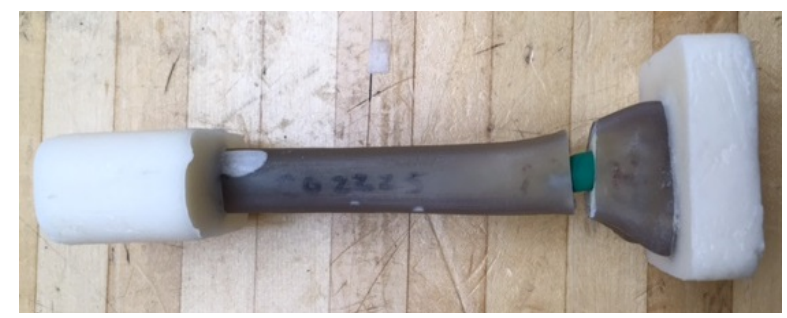

(a)

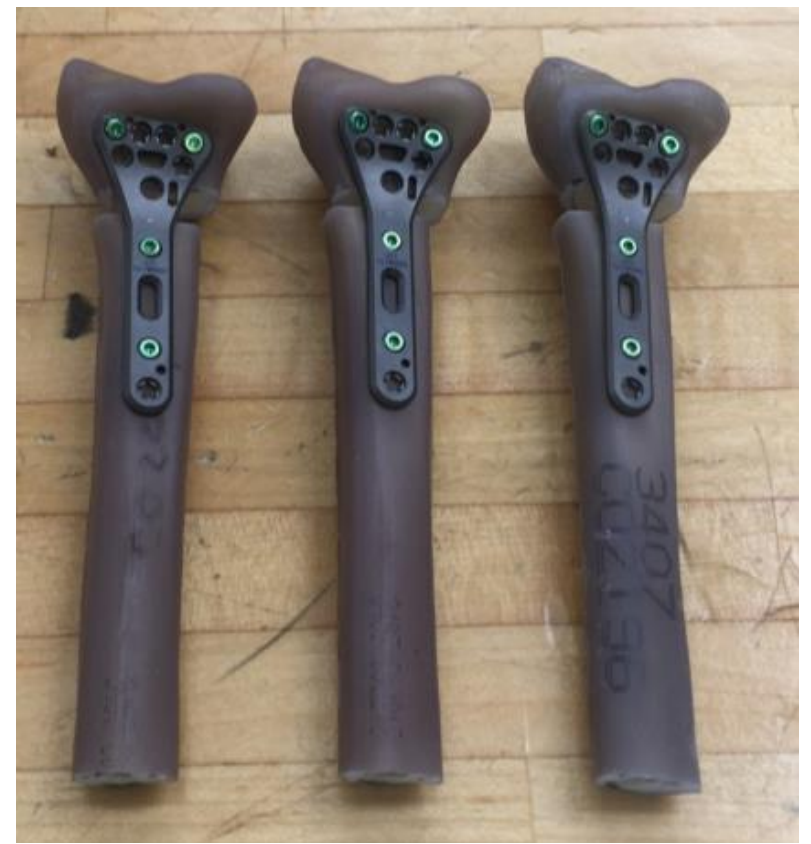

(b)

Figure 1. Photographs of potted SIPBO Construct (Green member: degradable balloon) (a) and as-prepared SVLP Constructs. (Green members: screws used to attach the plate to the Sawbones) (b). 


\subsection{Preparation of Intramedullary Injectable Bioresorbable Polymer System Construct}

To mitigate the risk of polymer extravasation, a Latex balloon was used as a containment vessel. The angle of entry into the intramedullary (IM) canal of the Sawbones was evaluated using 14-mm-diameter additive-manufactured (via selective laser sintering (SLS)) poly (etheretherketone) (PEEK) tubes, with this diameter being the mean diameter of the shaft of the Sawbones. Through a parametric study involving varying the inner diameter of the tube and the entry angle, the final choice was IM canal diameter of $7 \mathrm{~mm}, 30^{\circ}$ lateral entry portal in the anterior-posterior view, and a $15^{\circ}$ portal in the lateral view.

The Sawbones constructs were prepared using 1.4-mm-diameter Kirschner wires to target the IM canal from the distal aspect of the Sawbones. A bandsaw attached to an SLS-manufactured PEEK fixture was used to create a 4-mm wide fracture gap centrally placed $25 \mathrm{~mm}$ from the distal aspect of the radius.

An SLS-manufactured PEEK fixture was used to secure the Sawbones during injection of the bioresorbable polymer. Then, the balloon was inserted from the distal entry portal through the proximal aspect of the canal, after which a selfsealing membrane was used to attach the balloon to a degassing injection valve. An SLS-manufactured PEEK tube was inserted through the valve into the bottom of the balloon, after which the balloon was connected to a syringe (Figure 2).

The polymer was mixed in a vacuum chamber at room temperature, poured into the syringe, from which it was slowly injected into the balloon. During the injection, one person held the syringe and ensured that balloon pressure was maintained, while another person tied off the balloon once the injection appeared to reach sufficient volume and pressure. This caused the polymer to ex-

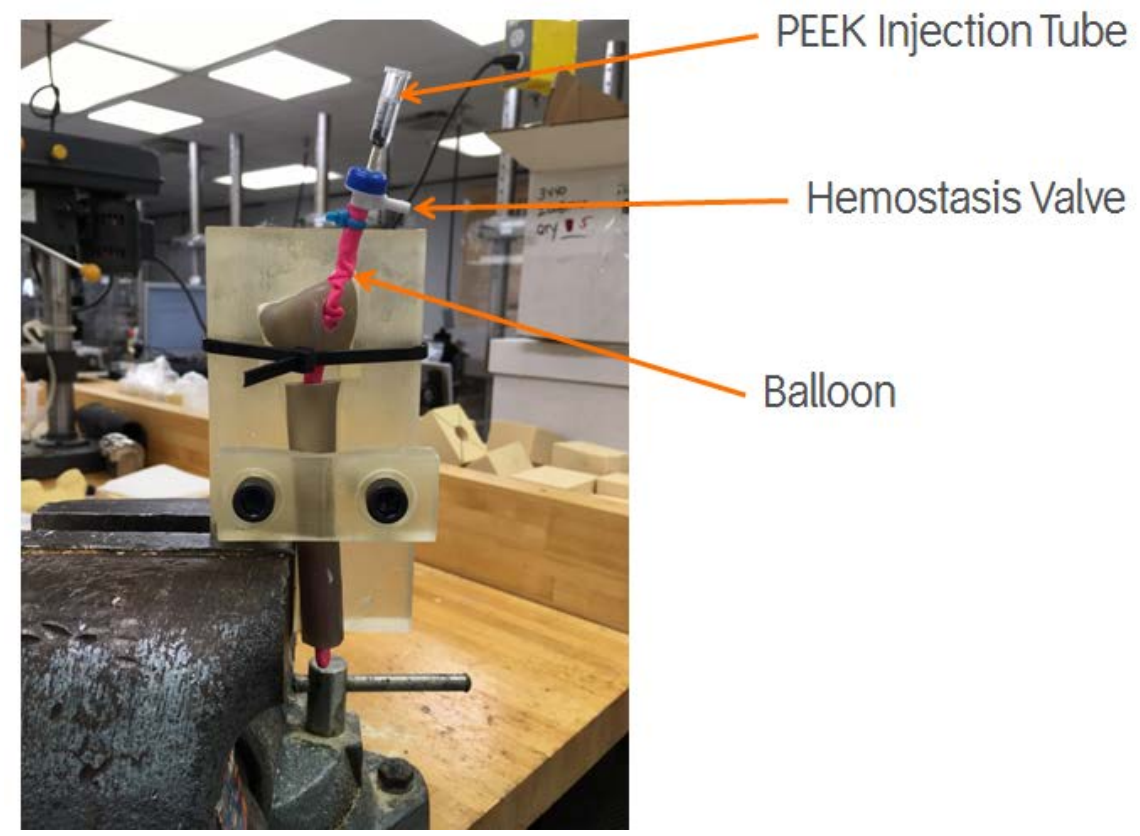

Figure 2. Photograph of the SIPBO Construct preparation platform. 
pand into the fracture gap. After that, the polymer was left to cure for a minimum of $24 \mathrm{~h}$ before the construct (Figure 1(a)) was removed from the preparation platform.

\subsection{Preparation of Volar Locking Plate Construct}

The approved Ti-6Al-4V alloy VLP system (D-RAD SmartPack'; Smith \& Nephew Orthopaedics, Memphis, TN, USA) was prepared by placing two screws in the head of the plate, at the radial and ulnar aspects of the distal row of the plate, two screws in the proximal aspect of the shaft of the plate, and drilling of the Sawbones. The simulated fracture was created in the Sawbones using the same method as was used in the preparation of the SIPBO constructs (see sub-section 2.2). The plate system was then attached to the Sawbones using the predrilled holes, thereby yielding the volar locking plate construct (Figure 1(b)).

\subsection{Testing Method and Loading Protocol}

The tests were carried out using a universal materials testing machine (MTS Systems Corp., Eden Prairie, MN, USA) (Figure 3). The construct was initially

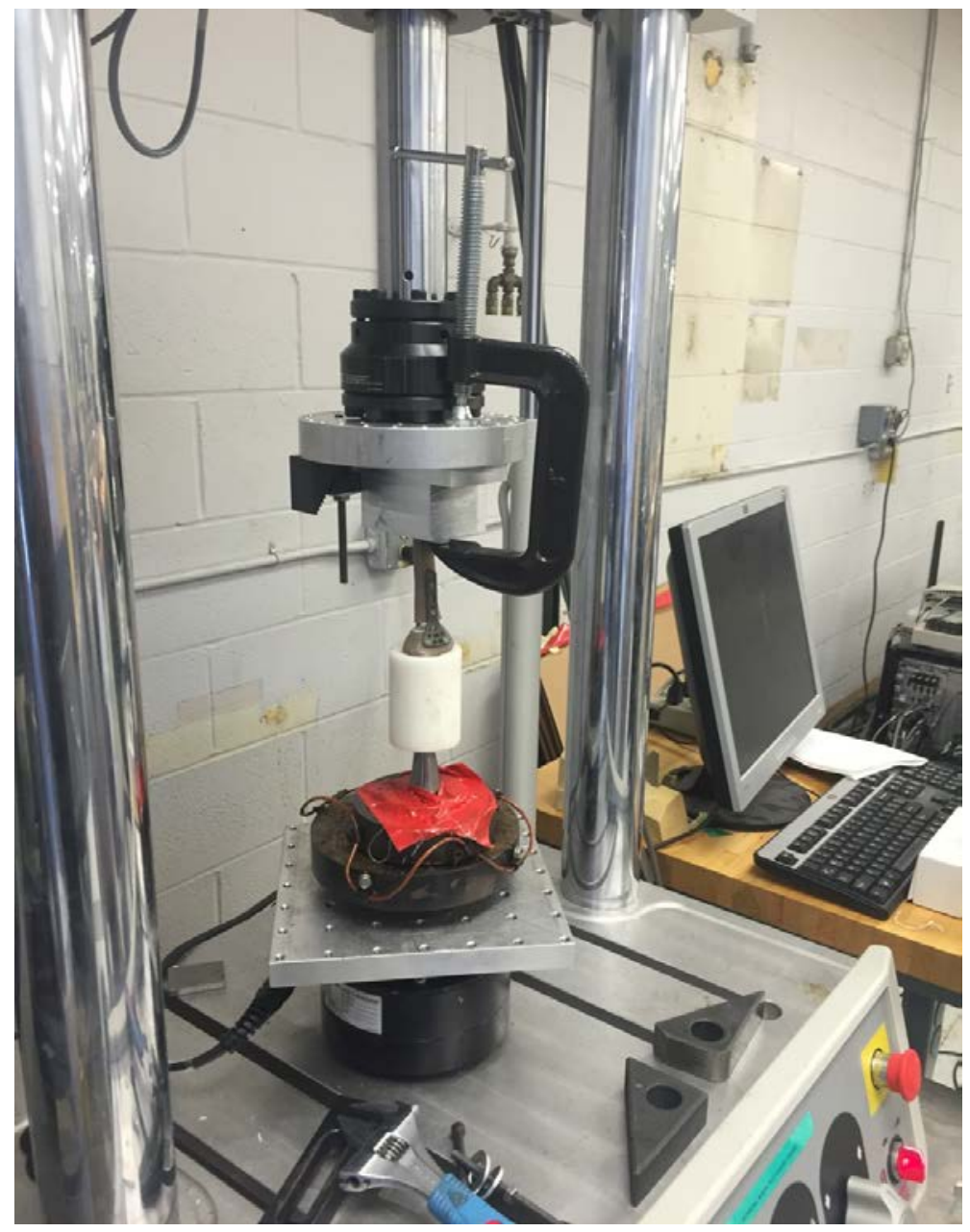

Figure 3. Photograph of a construct in the materials testing machine ready for the compression test. 
loaded, in axial compression, to a maximum load of $100 \mathrm{~N}$, simulating the loading experienced at the distal radius during active gripping [20] [21] [22]. Each construct was then subjected to a quasi-static loading (between $50 \mathrm{~N}$ and $100 \mathrm{~N}$, for 5000 cycles, at a rate of $2 \mathrm{~Hz}$ ), which simulates the loading experienced at a surgically-treated fractured DRF during a 6-week healing period or is imposed during exercises carried out as part of a physical therapy regimen after surgery [20] [21] [23]. Finally, the construct was compressively loaded, at a displacement rate of $2.5 \mathrm{~mm} \mathrm{~min}^{-1}$, until either failure occurred or the upper limit of the load cell in the testing machine was reached $\left(\mathrm{P}_{\max }=2500 \mathrm{~N}\right)$. Initial stiffness (slope of the initial linear portion of the load $(\mathrm{P})$-versus crosshead displacement $(\Delta)$ plot) (ICLS) and final stiffness (slope of the final linear portion of the load (P)-versus$\Delta$ plot) (FCLS) were computed and load-to-failure $\left(\mathrm{P}_{\mathrm{f}}\right)$ was recorded. If the construct fractured, it was photographed using a digital camera. For each of the study groups, three constructs were tested $(n=3)$.

\subsection{Statistical Analysis}

Quantitative results are presented as mean \pm population standard deviation. Intergroup comparison of quantitative results was performed using the KruskalWallis test and a commercially-available software package (SPSS, version 23; IBM Analytics, Armonk, NY, USA). Significance was denoted when $\mathrm{p}<0.05$.

\section{Results and Discussion}

A typical load-versus-construct displacement plot is shown in Figure 4.

ICLS of SIPBO Construct was within the range of that of SVLP Construct, with the same trend found for FCLS and for $\mathrm{P}_{\mathrm{f}}$ (Table 1). Each of the SIPBO constructs failed, with the location of failure being in the polymer, which is attributed to insufficient polymer expansion within the fracture gap (Figures 5(a)-(c)). Each of the SVLP constructs failed, with failure occurring in the proximal fragments of the radii and no failures occurring in the plates. SVLP Constructs \#1 and 2 appeared to crack due to dorsal displacement of the radial head fragment, resulting in a fracture of the cortical wall as the bone contacting the surface of the plate exerted a high-magnitude force on the cortical wall (Figure 6(a) and Figure 6(b)). For SVLP Construct \#3, there was a small frac-

Table 1. Compilation of the present results for initial compressive longitudinal stiffness, final compressive longitudinal stiffness, and load-to-failure for the 3 study cases.

\begin{tabular}{|c|c|c|c|}
\hline Case & $\begin{array}{l}\text { Initial stiffness } \\
\quad\left(\mathrm{N} \cdot \mathrm{mm}^{-1}\right)\end{array}$ & $\begin{array}{l}\text { Final stiffness } \\
\left(\mathrm{N} \cdot \mathrm{mm}^{-1}\right)\end{array}$ & $\begin{array}{l}\text { Load-to-failure } \\
\text { (N) }\end{array}$ \\
\hline $\begin{array}{l}\text { Intact synthetic distal radius } \\
\text { (4th generation Sawbones })\end{array}$ & $1372 \pm 274$ & $1925 \pm 452$ & $1860 \pm 135$ \\
\hline $\begin{array}{l}\text { Prototype Intramedullary injectable } \\
\text { bioresorbable polymer-bioresobable balloon } \\
\text { osteosynthesis construct (SIPBO Construct) }\end{array}$ & $225 \pm 191$ & $171 \pm 191$ & $157 \pm 124$ \\
\hline $\begin{array}{c}\text { Volar locking plate construct } \\
\text { (SVLP Construct) }\end{array}$ & $569 \pm 542$ & $469 \pm 239$ & $566 \pm 371$ \\
\hline
\end{tabular}




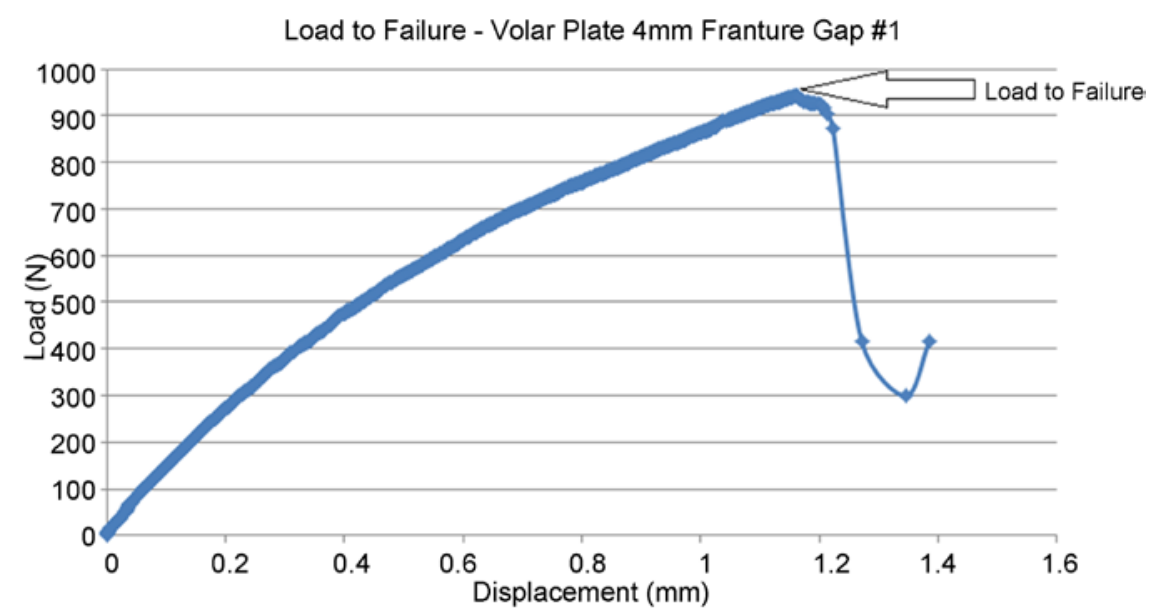

(a)

\section{Initial Conditioning - Volar Plate 4mm Fracture Gap \#1}

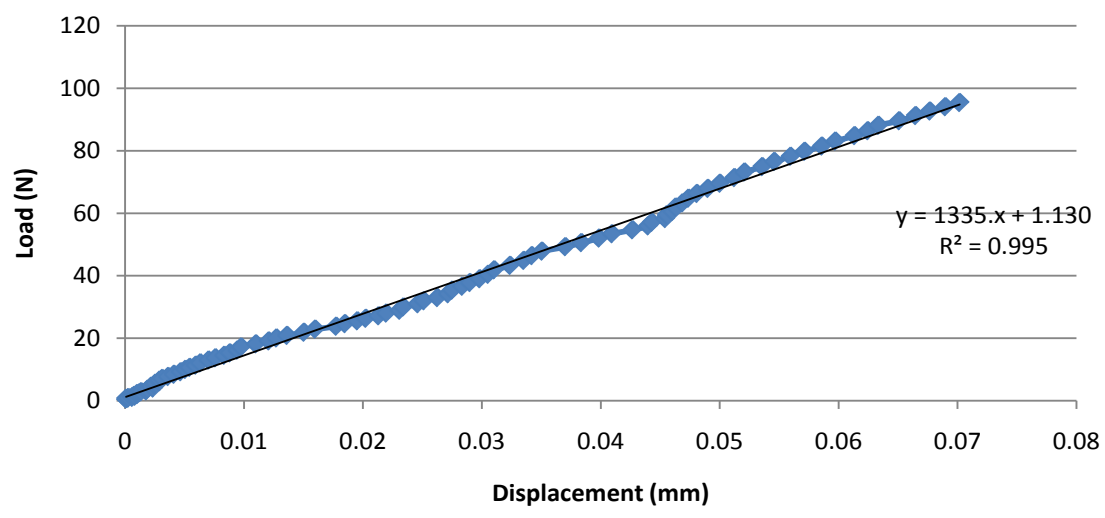

(b)

Figure 4. Typical load-versus-displacement plot for SVLP Construct \#1 (a), showing determination of Load-to-Failure (a) and initial stiffness (b).

Ture under the plate similar to that seen in the other plate constructs (Figure 6(c) and Figure 6(d)). Furthermore, for SVLP Construct \#3, it appears that the proximal and distal cortices contacted, resulting in chipping of the dorsal distal fragment and fracture of the dorsal proximal fragment (Figure 6(c) and Figure $6(d))$.

The quantitative biomechanical parameters determined for SVLP Construct are each comparable to results given in the literature for studies conducted using either fourth-generation Sawbones or cadaveric distal radii when differences between our studies and literature studies with regard to various features, notably, fracture type and loading protocol, are taken into account (Tables 2-4). In the case of intact distal radius, to the best of the present authors' knowledge, only two reports on one of these parameters $\left(\mathrm{P}_{\mathrm{f}}\right)$ have appeared in the experimental biomechanics literature. These are studies by Pistola et al. [34] and by Casagrande et al. [35], both on cadaveric distal radii. The present result for $\mathrm{P}_{\mathrm{f}}(1860 \pm$ $135 \mathrm{~N})$ is within the range reported by Pistola et al. [34] $(1240 \pm 460 \mathrm{~N})$ and that 


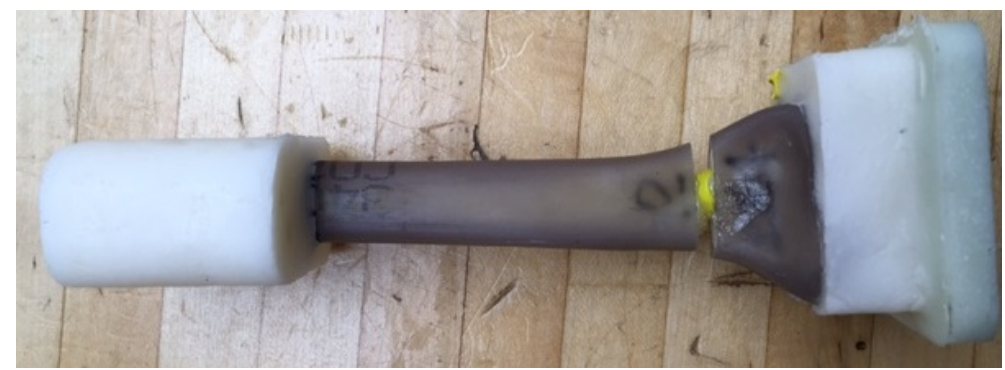

(a)

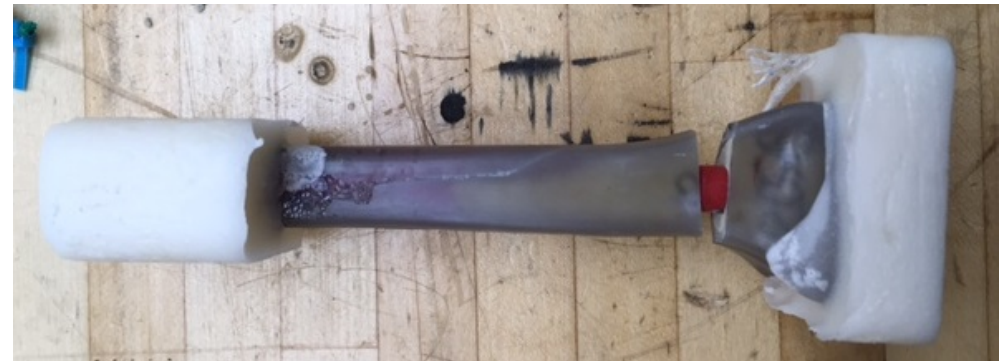

(b)

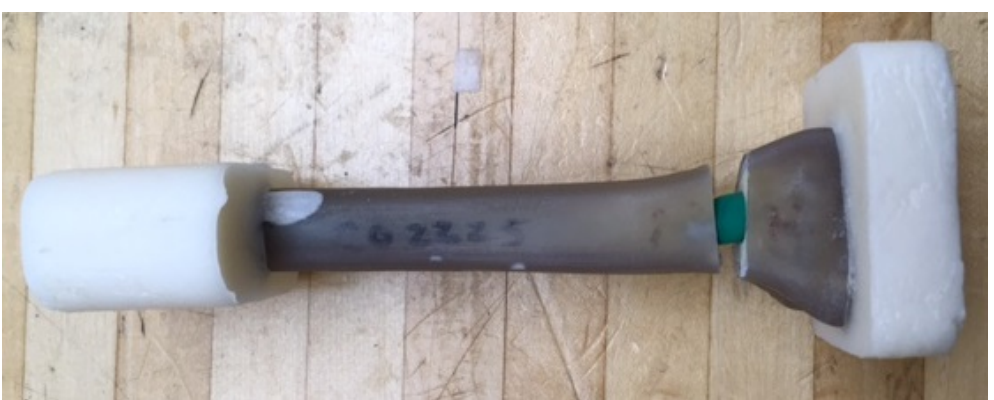

(c)

Figure 5. (a) Photograph of key features of fractured SIPBO Constructs: \#1; (b). Photograph of key features of fractured SIPBO Construct \#2.

Table 2. Summary of some features of relevant literature experimental biomechanical studies involving testing of constructs comprising a synthetic distal radius (fourth-generation Sawbones') with a simulated fracture and a fixed-angle volar locking plate and results for initial compressive longitudinal stiffness (ICLS), final compressive longitudinal stiffness (FCLS), and compressive load-to-failure $\left(\mathrm{P}_{\mathrm{f}}\right)$ of the construct.

\begin{tabular}{|c|c|c|c|c|}
\hline $\begin{array}{l}\text { Fracture type } \\
\text { simulated }\end{array}$ & $\begin{array}{l}\text { Method of creation of } \\
\text { simulated fracture }\end{array}$ & Loading protocol & $\begin{array}{c}\text { CLS (in N.mm }{ }^{-1} \text { ) and } \\
P_{f}(\text { in } N)\end{array}$ & Ref. \# \\
\hline $\begin{array}{l}\text { Dorsal wedge } \\
\text { fracture }\end{array}$ & $\begin{array}{l}10-\mathrm{mm} \text { dorsal wedge osteotomy } \\
\text { centered } 20 \mathrm{~mm} \text { proximal to the volar } \\
\text { articular margin of the lunate fossa }\end{array}$ & $\begin{array}{c}10 \mathrm{~N} \text { pre-load, followed by compressive force, at } 1 \\
\mathrm{~N} \cdot \mathrm{s}^{-1} \text {, from } 20 \mathrm{~N} \text { to } 100 \mathrm{~N} \text {; then, load, at } 1 \mathrm{~mm} \cdot \mathrm{min}^{-1} \text {, } \\
\text { to failure }\end{array}$ & $\begin{array}{c}\text { ICLS }=935 \pm 172^{\mathrm{a}} \\
\text { FCLS }=755 \pm 204^{\mathrm{a}} \\
\mathrm{P}_{\mathrm{f}}=430-550^{\mathrm{a}}\end{array}$ & $\begin{array}{c}\text { Sokol et al. } \\
\quad[24]\end{array}$ \\
\hline $\begin{array}{l}\text { Dorsal } \\
\text { comminuted } \\
\text { fracture }\end{array}$ & $\begin{array}{l}\text { 10-mm dorsal osteotomy at "an } \\
\text { identical distance", from the } \\
\text { distal dorsal tip of the radius }\end{array}$ & $\begin{array}{l}10 \mathrm{~N} \text { pre-load, then loaded, } \\
\text { at } 2 \mathrm{~N} \cdot \mathrm{s}^{-1} \text {, to } 100 \mathrm{~N} \text { (phase } 1 \text { ), or to } 200 \mathrm{~N} \text { (phase } 2 \text { ), } \\
\text { or to } 300 \mathrm{~N} \text { (phase } 3 \text { ). After each phase, cyclically } \\
\text { load }\left(\mathrm{R}^{\mathrm{c}}=10 ; 2 \mathrm{~Hz} \text { for } 2.000 \mathrm{cycles} \text { for a total of } 6.000\right. \\
\text { cycles. Then, loaded, at } 2 \mathrm{~N} \cdot \mathrm{s}^{-1} \text {, to failure }\end{array}$ & ICLS $=140-470^{\mathrm{b}}$ & Dahl et al. [25] \\
\hline $\begin{array}{l}\text { AO type } \mathrm{C} 2 \\
\text { fracture }\end{array}$ & $\begin{array}{l}10-\mathrm{mm} \text { dorsal wedge centered } \\
20 \mathrm{~mm} \text { from the articular } \\
\text { margin of the distal radius }\end{array}$ & $\begin{array}{l}\text { Pre-load of up to } 100 \mathrm{~N} \text {, then cyclically loaded, at } 1 \\
\mathrm{~Hz} \text {, between } 50 \mathrm{~N} \text { and } 100 \mathrm{~N} \text {, for 2,000 cycles. Then, } \\
\text { loaded to failure }\end{array}$ & $\begin{array}{l}\text { ICLS }=129-994^{d} \\
\text { FCLS }=33-143^{d} \\
P_{f}=329-1517^{d}\end{array}$ & $\begin{array}{c}\text { Drobetz et al. } \\
{[26]}\end{array}$ \\
\hline
\end{tabular}

${ }^{a}$ Results are presented for tests on constructs containing 1 volar plating system design. ${ }^{b}$ Results are presented are for tests on constructs containing 8 different volar plating system designs. ${ }^{\mathrm{c}}$ (Minimum load applied during the loading cycle)/(maximum load applied during the loading cycle). ${ }^{\mathrm{d}}$ Results are presented for tests on constructs containing 5 different volar plating system designs. 


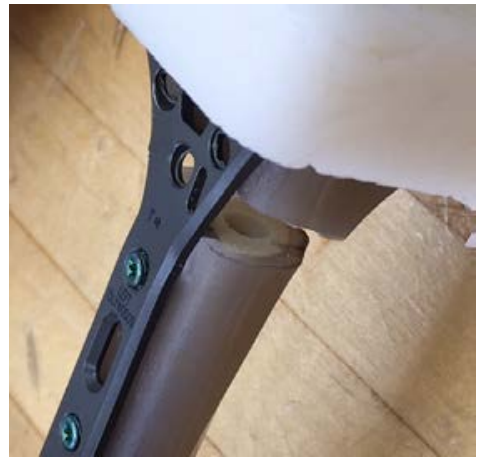

(a)

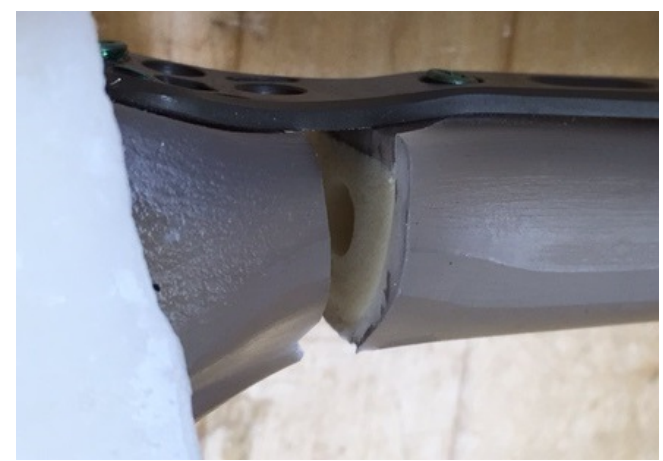

(b)

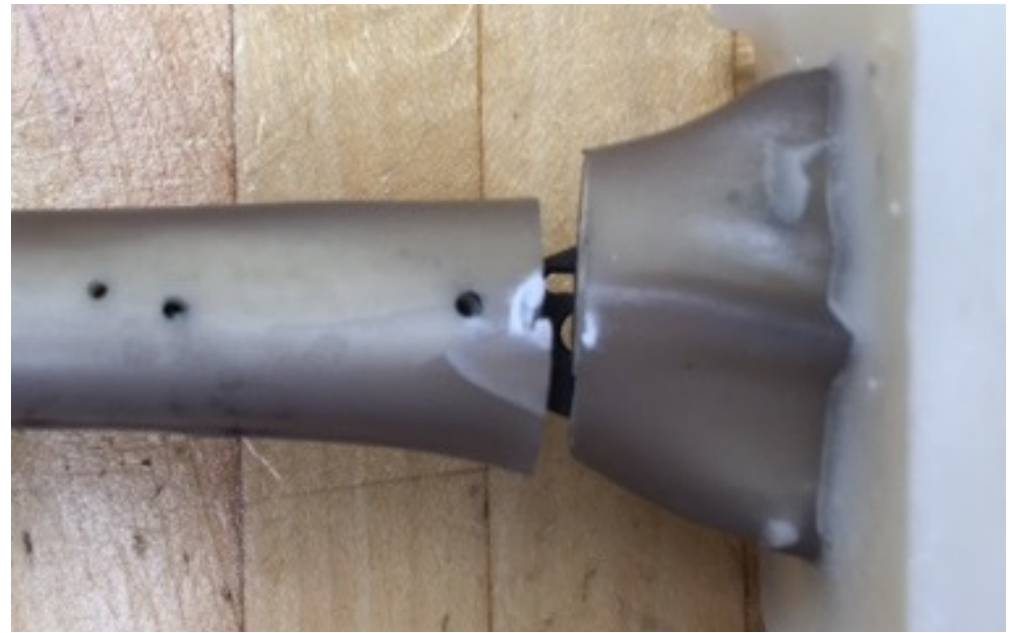

(c)

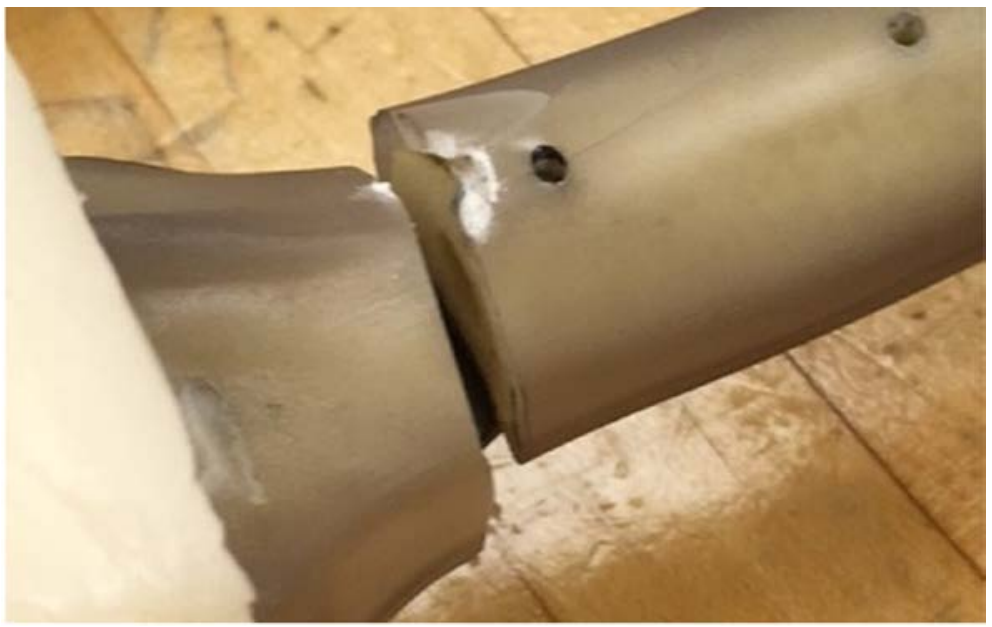

(d)

Figure 6. (a) (b) Photographs of key features of fractured SVLP Constructs: \#1 (a); \#2 (b); (c) (d). Photographs of key features of fractured SVLP Construct \#3 (c ) and (d).

reported by Casagrande et al. [35] (1780 N - $5200 \mathrm{~N}$ for cadavers having cortical bone density in the range 480 - 845 Hounsfield Units. The aforementioned excellent comparisons give credibility to the present quantitative results obtained for the SVLP Construct and, since all the test conditions were the same for SVLP and SIPBO Constructs, the SIPBO Construct results are also credible. 
Table 3. Summary of some features of relevant literature biomechanical studies involving testing of constructs comprising a fresh-frozen cadaveric distal radius with a simulated fracture and a Ti-6Al-4V alloy fixed-angle volar locking plate and results for compressive longitudinal stiffness (CLS) and load-to-failure $\left(\mathrm{P}_{\mathrm{f}}\right)$ of the construct.

\begin{tabular}{|c|c|c|c|c|}
\hline $\begin{array}{l}\text { Fracture type } \\
\text { simulated }\end{array}$ & $\begin{array}{l}\text { Method of creation of } \\
\text { simulated fracture }\end{array}$ & Loading protocol & $\mathrm{CLS}\left(\mathrm{N} \cdot \mathrm{mm}^{-1}\right) ; \mathrm{P}_{\mathrm{f}}$ & Ref. \# \\
\hline $\begin{array}{l}\text { Comminuted, } \\
\text { extra-articular, } \\
\text { dorsally-unstable } \\
\text { fracture }\end{array}$ & $\begin{array}{c}\text { Osteotomy created } 20 \mathrm{~mm} \\
\text { proximal to the articular } \\
\text { surface at the Lister tubercle; then, } \\
6 \text {-mm-wide } \\
\text { dorsally-based wedge removed }\end{array}$ & $\begin{array}{l}\text { Axial compression, at } 1 \mathrm{~N} \cdot \mathrm{s}^{-1} \text {, } \\
\text { to a maximum load of } 90 \mathrm{~N}\end{array}$ & $\begin{array}{c}430 \pm 200\left(\text { load applied at center }{ }^{\mathrm{a}}\right) \\
340 \pm 140\left(\text { load applied radial off-center }{ }^{\mathrm{a}}\right) \\
440 \pm 200\left(\text { load applied ulnar off-center }{ }^{\mathrm{a}}\right) \\
250 \pm 110(\text { load applied volar off-center }) \\
150 \pm 92\left(\text { load applied dorsal off-center }{ }^{\mathrm{a}}\right)\end{array}$ & $\begin{array}{l}\text { Liporice } \\
\text { et al. [20] }\end{array}$ \\
\hline $\begin{array}{l}\text { Dorsally- } \\
\text { comminuted } \\
\text { fracture }\end{array}$ & $\begin{array}{c}\text { An incomplete } 1 \text {-mm wide dorsal wedge } \\
\text { osteotomy that started } 2 \\
0 \mathrm{~mm} \text { from the articular surface }\end{array}$ & $\begin{array}{l}\text { Cyclically loaded, at } 100 \mathrm{~N} \cdot \mathrm{s}^{-1} \text {, } \\
\text { from preload of } 100 \mathrm{~N} \text { to a } \\
\text { compression load of } 250 \mathrm{~N} \text {. } \\
\text { Either } 5,000 \text { or } 20,000 \text { cycles } \\
\text { at } 1 \mathrm{~Hz}\end{array}$ & $\begin{array}{c}400 \pm 100 \\
\mathrm{P}_{\mathrm{f}}=1000 \pm 300 \mathrm{~N}\end{array}$ & $\begin{array}{l}\text { Blythe } \\
\text { et al. [23] }\end{array}$ \\
\hline $\begin{array}{l}\text { Extra-articular, } \\
\text { severe comminuted } \\
\text { fracture }\end{array}$ & $\begin{array}{c}\text { 10-mm gap (10 mm volar height, } 10 \mathrm{~mm} \\
\text { dorsal height, } 10 \mathrm{~mm} \text { radial height, } 10 \\
\mathrm{~mm} \text { ulnar height), } 20 \mathrm{~mm} \text { from the } \\
\text { distal articular surface }\end{array}$ & $\begin{array}{l}\text { Loaded, at } 2 \mathrm{~mm} \mathrm{~s}^{-1} \text {, to failure } \\
\text { in axial } \\
\text { compression }\end{array}$ & $\begin{array}{c}107 \pm 32 \\
\mathrm{P}_{\mathrm{f}}=822 \pm 448 \mathrm{~N}\end{array}$ & $\begin{array}{l}\text { Osada } \\
\text { et al. [27] }\end{array}$ \\
\hline $\begin{array}{l}\text { Colles-type } \\
\text { extra-articular } \\
\text { fracture }\end{array}$ & $\begin{array}{l}\text { 15-mm dorsally-based wedge } \\
\text { osteotomy, centered } 22.5 \mathrm{~mm} \\
\text { proximal to the articular margin } \\
\text { at Lister's tubercle }\end{array}$ & $\begin{array}{l}3 \text { initial loading ramps to } 300 \\
\mathrm{~N} \text { compression, at } 1 \mathrm{~N} \cdot \mathrm{s}^{-1}\end{array}$ & $\begin{array}{c}137 \pm 51 \text { (large plate) } \\
153 \pm 34 \text { (small plate) } \\
\mathrm{P}_{\mathrm{f}}=747 \pm 227 \mathrm{~N} \text { (large plate) } \\
\mathrm{P}_{\mathrm{f}}=919 \pm 197 \mathrm{~N} \text { (small plate) }\end{array}$ & $\begin{array}{c}\text { Koh } \\
\text { et al. [28] }\end{array}$ \\
\hline $\begin{array}{l}\text { Severely } \\
\text { comminuted, } \\
\text { fracture }\end{array}$ & $\begin{array}{l}\text { Transverse osteotomy } 20 \mathrm{~mm} \\
\text { unstable, extra-articular proximal } \\
\text { to the articular surface; then, } 15-\mathrm{mm} \\
\text { fracture gap created making a second } \\
\text { transverse osteotomy } 15 \mathrm{~mm} \\
\text { proximal to the initial osteotomy }\end{array}$ & $\begin{array}{c}\text { Axial compression, at } 1 \mathrm{~N} \cdot s-1 \text {, } \\
\text { to a maximum load of } 50 \mathrm{~N}\end{array}$ & $\begin{array}{c}460 \pm 10 \\
\left(\text { load applied at central location }{ }^{\mathrm{a}}\right) \\
150 \pm 2(\text { load applied at dorsal location }) \\
240 \pm 3(\text { load applied at volar location })\end{array}$ & $\begin{array}{l}\text { Strauss } \\
\text { et al. [29] }\end{array}$ \\
\hline $\begin{array}{l}\text { Extra-articular } \\
\text { AO-type A3 } \\
\text { fracture }\end{array}$ & $\begin{array}{l}\text { Excision of } 10 \text {-mm wide bone } \\
\text { segment, centered } 20 \mathrm{~mm} \\
\text { proximal to the tip of the } \\
\text { radial styloid }\end{array}$ & $\begin{array}{l}\text { Static axial compression } \\
\text { force of } 250 \mathrm{~N}\end{array}$ & $\begin{array}{l}83 \pm 62 \text { ( } 4 \text { locking screws in the distal row } \\
\text { of the plate); } P_{\mathrm{f}}=99 \pm 60 \mathrm{~N} \\
208 \pm 60 \text { ( } 4 \text { locking screws alternately in } \\
\text { the distal and proximal rows of the plate); } \\
\mathrm{P}_{\mathrm{f}}=228 \pm 56 \mathrm{~N} ; 178 \pm 82 \text { ( } 3 \text { locking } \\
\text { screws the proximal row of the plate); } \\
\mathrm{P}_{\mathrm{f}}=245 \pm 48 \mathrm{~N} ; 429 \pm 224 \text { (7 locking } \\
\text { screws filling all screw holes in the distal } \\
\text { and proximal rows of the plate); } \\
\mathrm{P}_{\mathrm{f}}=305 \pm 106 \mathrm{~N}\end{array}$ & $\begin{array}{l}\text { Mehling } \\
\text { et al. [30] }\end{array}$ \\
\hline $\begin{array}{l}\text { Extra-articular } \\
\text { OTA-type 23-A3 } \\
\quad \text { fracture }\end{array}$ & $\begin{array}{l}\text { Excision of } 10-\mathrm{mm} \text { wide dorsal } \\
\text { wedge, centered } 20 \mathrm{~mm} \text { from the } \\
\text { articular margin of the distal radius }\end{array}$ & $\begin{array}{l}\text { Static axial compression force } \\
\text { of } 130 \mathrm{~N}\end{array}$ & $\begin{array}{l}188 \pm 53 \text { (4 locking screws in the distal } \\
\text { row of the plate and } 3 \text { locking screws in } \\
\text { the proximal row of the plate) }\end{array}$ & $\begin{array}{l}\text { Mehling } \\
\text { et al. }[31]\end{array}$ \\
\hline $\begin{array}{l}\text { Extra-articular } \\
\text { OA-23 A3 } \\
\text { fracture }\end{array}$ & $\begin{array}{l}\text { A dorsal wedge osteotomy, } \\
\text { completely separating the } \\
\text { volar cortex ( } 1 \mathrm{~mm} \text { gap) }\end{array}$ & $\begin{array}{c}\text { Static axial compression force, } \\
\text { at } 1 \mathrm{~mm} \mathrm{~s}^{-1} \text {, until either a } 20 \% \\
\text { drop in force or } 3 \mathrm{~mm} \\
\text { displacement is reached }\end{array}$ & $\begin{array}{l}706 \pm 103 \text { (distal screw tips are flushed } \\
\text { with or are just short of the distal cortex } \\
\text { (Group A; } 660 \pm 124 \text { (target screw length) } \\
=75 \% \text { of that in Group A construct) }\end{array}$ & $\begin{array}{l}\text { Baumbach } \\
\text { et al. [32] }\end{array}$ \\
\hline $\begin{array}{l}\text { 4-part AO C3 } \\
\text { fracture }\end{array}$ & $\begin{array}{l}\text { With all soft tissues in place, a } 15-\mathrm{mm} \\
\text { wedge osteotomy created } 20 \mathrm{~mm} \\
\text { proximal to the articular surface; volar } \\
\text { cortex fractured manually; } 2 \mathrm{nd} \\
\text { osteotomy created directly ulnar to the } \\
\text { Lister tubercle in sagittal plane; } 3 \mathrm{rd} \\
\text { osteotomy created coronally in the } \\
\text { medial fragment; and, then, coronal cut } \\
\text { made from fracture site to articular } \\
\text { surface of the radius }\end{array}$ & $\begin{array}{l}\text { Pre-load of } 100 \mathrm{~N} \text {; then, } \\
\text { cyclical loading }(20 \mathrm{~N}-230 \\
\mathrm{N}) \text {, at } 2 \mathrm{~Hz} \text {, for } 6000 \text { cycles; } \\
\text { finally, load to failure, } \\
\quad \text { at } 2 \mathrm{~mm} \cdot \mathrm{s}^{-1}\end{array}$ & $\begin{array}{c}379 \pm 146 \\
\mathrm{P}_{\mathrm{f}}=1109 \pm 305 \mathrm{~N}\end{array}$ & $\begin{array}{l}\text { Marshall } \\
\text { et al. [33] }\end{array}$ \\
\hline
\end{tabular}

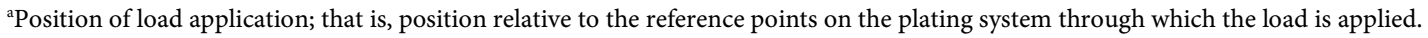


Table 4. Fixed-angle volar locking plate construct: comparison of range of the present results for compressive longitudinal stiffness (CLS) and compressive load-to-failure $\left(\mathrm{P}_{\mathrm{f}}\right)$ with relevant results from the literature.

\begin{tabular}{cccc}
\hline Biomechanical parameter & Present study & $\begin{array}{c}\text { Literature results using } \\
\text { fourth-generation Sawbones }^{\text {b }}\end{array}$ & $\begin{array}{c}\text { Literature results fresh-frozen } \\
\text { cadaveric distal radiic }^{c}\end{array}$ \\
\hline CLS $\left(\mathrm{N} \cdot \mathrm{mm}^{-1}\right)$ & $27-1111$ & $33-1107$ & $21-809$ \\
$\mathrm{P}_{\mathrm{f}}(\mathrm{N})$ & $195-937$ & $140-1517$ & $39-1414$ \\
\hline
\end{tabular}

a See Table 1. 'bee Table 2. 'See Table 3.

The VLP system used in our SVLP Construct is in clinical use all over the world. Thus, comments made in the immediate preceding two paragraphs suggest that the IPBO system is plausible and, as such, merits further evaluation so that it may be optimized before undergoing in vitro evaluation in a suitable animal model. Optimization studies could involve, for example, determining a) the influence of polymer mixing variables on the viscosity-versus-mixing time profile of the polymer; $b$ ) the influence of the aforementioned profile on the fracture gap fill ratio (FGFR) (herein defined as the proportion of the fracture gap that is filled with the expanding balloon as the polymer is being injected into it); and c) the influence of FGFR on the biomechanical parameters considered in the present study as well as others, such as the fatigue life of the construct.

In addition to the demonstration of the plausibility of the IPBO system as a novel surgical modality for treating DRFs, the present study has two other attractive features. First, values of biomechanical parameters for intact Sawbones were determined, which allowed us to suggest that, based on the results reported by Casagrande et al. [35], the present $\mathrm{P}_{\mathrm{f}}$ result corresponds to that of a cadaver having cortical bone density in the range of 480 - 500 Hounsfield Units, which, in turn, corresponds to a person aged $>65$ years [35], for whom the incidence of DRF is very high [2]. Second, descriptions of key features seen in fractured SIPBO Construct and SVLP Construct are included in the present contribution; in contrast, this type of information was not given in any of the above-referenced relevant literature reports [24]-[33]. Reports of fracture/breakage of volar locking plates in clinical series are very scarce, with the only one that we are aware of being by Imade et al. [36]. These workers reported one such case (breakage occurred $1 \mathrm{wk}$ post-surgery in a 56-yr-old man who had sustained an $\mathrm{AO} / \mathrm{ASIF}$ C2 fracture type) and attributed the cause of the breakage to an error in screw position [36]. Thus, since there was no breakage or any type of failure in any of the screws in any of the SVLP constructs, the suggestion is that the screws were positioned properly.

Two limitations of the study are recognized. First, in each of the study groups, the sample size was small $(n=3)$. Second, the biomechanical tests were conducted in ambient laboratory conditions rather than in a biosimulating medium (such as phosphate buffered saline solution, at $37^{\circ} \mathrm{C}$ ).

Since the results of the present study show that the IPBO system is plausible, it is worthwhile to highlight potential advantages and shortcomings of this system when used in the clinical setting. Three potential advantages are noted. First, its 
placement would involve only a small incision and, hence, tissue resection (that is, it would be minimally invasive). This avoids the release of tendons associated with standard dorsal approaches, such as the extensor pollicis longus, brachioradialis, and extensor carpal radialis brevis, while reducing the risk of nerve palsy arising from complications that involve the radial nerve. Second, anti-rotation and stability may be achieved by the irregularities associated with the medullary canal geometries, thus obviating the need for additional fixation methods to stabilize fragments, which, in turn, reduces cost and reduces opportunities for error. Third, the system could facilitate superior DRF reduction in patients who have poor bone quality (for example, those who are osteoporotic) because it does not rely on purchase of fasteners in bone. One potential challenge of this system is that it may require increased use of intra-operative fluoroscopy to ensure that the canal is targeted appropriately.

\section{Conclusions}

We found that:

- Initial longitudinal stiffness, final longitudinal stiffness, and load-to-failure of a construct that comprised a clinically-relevant fracture created in a synthetic distal radius (fourth-generation Sawbones) that was fixated using the IPBO system (SIPBO Construct) were each within the range of that of a construct in which the fracture was fixated using an approved Ti-6Al-4V VLP system (SVLP Construct). This suggests that the IPBO system is plausible and, as such, merits further study.

- For SIPBO Construct, all of the fractures were located within the polymer zone, whereas, for SVLP Construct, the main failure features were fracture of the cortical wall and of the dorsal proximal fragments.

\section{Acknowledgements}

The authors thank Smith \& Nephew, Memphis, TN, USA, for donation of all the materials used in this study and for use of their materials testing laboratories. The authors express their gratitude to the following professionals, all employed by Smith \& Nephew: Mr. Ed Austin and Dr. Si Janna (for help in the design of the study).

\section{References}

[1] Simic, P.M. and Weiland, A.J. (2003) Fractures of the Distal Aspect of the Radius: Changes in Treatment over the Past Two Decades. Instructional Course Lectures Journal, 52, 185-195. https://doi.org/10.2106/00004623-200303000-00026

[2] Suojärvi, N., Sillat, T., Lindfors, N. and Koskinen, S.K. (2015) Radiographical Measurements for Distal Intra-Articular Fractures of the Radius Using Plain Radiographs and Cone Beam Computed Tomography Images. Skeletal Radiology, 44, 1769-1775. https://doi.org/10.1007/s00256-015-2231-4

[3] Schneppendahl, J., Windolf, J. and Kaufmann, A. (2012) Distal Radius Fractures: Current Concepts. Journal of Hand Surgery, 37A, 1718-1725. https://doi.org/10.1016/j.jhsa.2012.06.001 
[4] Diaz-Garcia, R.J. and Chung, K.C. (2012) The Evolution of Distal Radius Fracture Management: A Historical Treatise. Hand Clinics, 28, 105-111. https://doi.org/10.1016/j.hcl.2012.02.007

[5] Henry, M.H. (2008) Distal Radius Fractures: Current Concepts. Journal of Hand Surgery, 33A, 1215-1227. https://doi.org/10.1016/j.jhsa.2008.07.013

[6] Obert, L., Rey, P.B., Uhring, J., Gasse, N., Rochet, S., Lepage, D., Serre, A. and Garbuio, P. (2013) Fixation of Distal Radius Fractures in Adults: A Review. Orthopaedics \& Traumatology: Surgery \& Research, 99, 216-234. https://doi.org/10.1016/j.otsr.2012.03.023

[7] Horst, T.A. and Jupiter, J.B. (2016) Stabilisation of Distal Radius Fractures: Lessons Learned and Future Directions. Injury, 47, 313-319. https://doi.org/10.1016/j.injury.2015.09.030

[8] Strassmair, M.K., Jonas, M., Schäfer, W. and Palmer, A. (2016) Distal Radial Fracture Management with an Intramedullary Cage and Fragment Fixation. Journal of Hand Surgery, 41A, 833-840.

[9] Taras, J.S., Saillant, J.C., Goljan, P and McCabe, L.A. (2016) Distal Radius Fracture Fixation with the Specialized Hreaded Pin Device. The American Journal of Orthopedics, 39, 98-103.

[10] Hardman, J., Al-Hadithy, N., Hester, T. and Anakwe, R. (2015) Systematic Review of Outcomes Following Fixed Angle Intramedullary Fixation of Distal Radius Fractures. International Orthopaedics, 39, 2381-2387.

https://doi.org/10.1007/s00264-015-2763-1

[11] Brogren, E., Petranek, M. and Atroshi, I. (2015) Cast-Treated Distal Radius Fractures: A Prospective Cohort Study of Radiological Outcomes and Their Association with Impaired Calcaneal Bone Mineral Density. Archives of Orthopaedic and Trauma Surgery, 135, 927-933. https://doi.org/10.1007/s00402-015-2220-Z

[12] Zhang, L.H., Wang, Y.N., Mao, Z, Zhang, L.C., Li, H.D., Yan, H., Liu, X.X. and Tang, P.F. (2015) Volar Locking Plate versus External Fixation for the Treatment of Unstable Distal Radial Fractures: A Meta-Analysis of Randomized Controlled Trials. Journal of Surgical Research, 193, 324-333.

https://doi.org/10.1016/j.jss.2014.06.018

[13] Zong, S.L., Kan, S.L., Su, L.X. and Wang, B. (2015) Meta-Analysis for Dorsally Displaced Distal Radius Fracture Fixation: Volar Locking Plate versus Percutaneous Kirschner Wires. Journal of Orthopaedic Surgery and Research, 10, 12 p.

[14] Alluri, R.K., Hill, J.R. and Ghiassi, A. (2016) Distal Radius Fractures: Approaches, Indications and Techniques. Journal of Hand Surgery, 41A, 845-854. https://doi.org/10.1016/j.jhsa.2016.05.015

[15] Orbay, J.L. and Fernandez, D.L. (2004) Volar Fixed-Angle Plate Fixation for Unstable Distal Radius Fractures the Elderly Patient. Journal of Hand Surgery, 29A, 96102.

[16] Burkhart, K.J., Nowak, T.E., Gradl, G., Klitscher, D., Mehling, I., Mehler, D., Mueller, L.P. and Rommens, P.M. (2010) Intramedullary Nailing vs. Palmar Locked Plating for Unstable Dorsally Comminuted Distal Radius Fractures: A Biomechanical Study. Clinical Biomechanics, 25, 771-775. https://doi.org/10.1016/j.clinbiomech.2010.06.004

[17] McCall, T.A., Conrad, B., Badman, B. and Wright, T. (2007) Volar versus Dorsal Fixed-Angle Fixation of Dorsally Unstable Extra-Articular Distal Radius Fractures: A Biomechanic Study. Journal of Hand Surgery, 32A, 806-812.

[18] Orbay, J.L., Touhahami, A. and Orbay, C. (2005) Fixed Angle Fixation of Distal Ra- 
dius Fractures through a Minimally Invasive Approach. Techniques in Hand \& Upper Extremity Surgery, 9, 142-148. https://doi.org/10.1097/01.bth.0000173374.97406.70

[19] Satake, H., Hanaka, N., Honma, R., Watanabe, T., Inoue, S., Kanauchi, Y., Kato, Y., Nakajima, T., Sato, D., Eto, J., Maruyama, M., Naganuma, Y., Sasaki, J., Toyono, S., Harada, M., Ishigaki, D., Takahara, M. and Takagi, M. (2016) Complications of Distal Radius Fractures Treated by Volar Locking Plate Fixation. The American Journal of Orthopedics, 39, 893-896.

[20] Liporace, F.A., Gupta, S., Jeong, G.K., Stracher, M., Kummer, F., Egol, K.A. and Koval, K.J. (2005) A Biomechanical Comparision of a Dorsal 3.5-mm T-Plate and a Volar Fixed-Angle Plate in a Model of Dorsally Unstable Distal Radius Fractures. Journal of Orthopaedic Trauma, 19, 187-191. https://doi.org/10.1097/00005131-200503000-00006

[21] Kandemir, U., Matityahu, A., Desai, R. and Puttitz, C. (2008) Does a Volar Locking Plate Provide Equivalent Stability as a Dorsal Nonlocking Plate in a Dorsally Comminuted Distal Radius Fracture? A Biomechanical Study. Journal of Orthopaedic Trauma, 22, 605-610. https://doi.org/10.1097/BOT.0b013e318186006f

[22] Obert, L., Loisel, F., Gasse, N. and Lepage, D. (2015) Distal Radius Anatomy Applied to the Treatment of Wrist Fractures by Plate: A Review Of Recent Literature. Journal of the Société Internationale de Chirurgie Orthopédique et de Traumatologie, $1,14$.

[23] Blythe, M., Stoffel, K., Jarrett, P. and Kuster, M. (2006) Volar versus Dorsal Locking Plates with and without Radial Styloid Locking Plates for Fixation of Dorsally Comminuted Distal Radius Fractures: A Biomechanical Study in Cadavers. Journal of Hand Surgery, 31A, 1587-1593. https://doi.org/10.1016/j.jhsa.2006.09.011

[24] Sokol, S.C., Amanatullah, D.F., Curtiss, S. and Szabo, R.M. (2011) Biomechanical Properties of Volar Hybrid and Locked Plate Fixation in Distal Radius Fractures. Journal of Hand Surgery, 36A, 591-597. https://doi.org/10.1016/j.jhsa.2010.12.032

[25] Dahl, W.J., Nassab, P.F., Burgess, K.M., Postak, P.D., Evans, P.J., Seitz, W.H., Greenwald, A.S. and Lawton, J.N. (2012) Biomechanical Properties of Fixed Angle Volar Distal Radius Plates under Dynamic Loading. Journal of Hand Surgery, 37A, 1381-1387. https://doi.org/10.1016/j.jhsa.2012.03.021

[26] Drobetz, H., Weninger, P., Grant, C., Heal, C., Muller, R., Schuetz, M., Pham, M. and Steck, R. (2013) More Is Not Ecessarily Better. A Biomechanical Study on Distal Screw Numbers in Volar Locking Distal Radius Lates. Injury, 44, 535-539.

[27] Osada, D., Viegas, S.F., Shah, M.A., Morris, R.P. and Patterson, R.M. (2003) Comparison of Different Distal Radius Dorsal and Volar Fracture Fixation Plates: A Biomechanical Study. Journal of Hand Surgery, 28A, 94-104.

https://doi.org/10.1053/jhsu.2003.50016

[28] Koh, S., Morris, R.P., Patterson, R.M., Kearney, J.P., Buford, W.L. and Viegas, S.F. (2006) Volar Fixation for Dorsally Angulated Extra-Articular Fractures of the Distal Radius: A Biomechanical Study. Journal of Hand Surgery, 31A, 771-779. https://doi.org/10.1016/j.jhsa.2006.02.015

[29] Strauss, E.J., Banerjee, D., Kummer, F.J. and Tejwani, N.C. (2008) Evaluation of a Novel, Nonspanning External Fixator for Treatment of Unstable Extra-Articular Fractures of the Distal Radius: Biomechanical Comparison with a Volar Locking Plate. Journal of Trauma and Acute Care Surgery, 64, 975-981. https://doi.org/10.1097/TA.0b013e3180eea9f0

[30] Mehling, I., Müller, L.P., Delinsky, K., Mehler, D., Ing, D., Burkhart, K.J. and Rommens, P.M. (2010) Number and Locations of Screw Fixation for Volar 
Fixed-Angle Plating of Distal Radius Fractures: Biomechanical Study. Journal of Hand Surgery, 35A, 885-891. https://doi.org/10.1016/j.jhsa.2010.03.027

[31] Mehling, I., Klitscher, D., Mehling, A.P., Nowak, T.E., Sternstein, W., Ing, D., Rommens, P.M. and Müller, L.P. (2012) Volar Fixed-Angle Plating of Distal Radius Fractures: Screws Versus Pegs-A Biomechanical Study in a Cadaveric Model. Journal of Orthopaedics and Traumatology, 26, 395-401.

[32] Baumbach, S.F., Synek, A., Traxler, H., Mutschler, W., Pahr, D. and Chevalier, Y. (2015) The Influence of Distal Screw Length on the Primary Stability of Volar Plate Osteosynthesis-A Biomechanical Study. Journal of Orthopaedic Surgery and Research, 10, 139. https://doi.org/10.1186/s13018-015-0283-8

[33] Marshall, T., Momaya, A., Eberhardt, A., Chaudhari, N. and Hunt, T.R. (2015) Biomechanical Comparison of Olar Fixed-Angle Locking Plates for AO C3 Distal Radius Fractures: Titanium versus Stainless Steel Ith Compression. Journal of Hand Surgery, 40A, 2032-2038. https://doi.org/10.1016/j.jhsa.2015.06.098

[34] Pistola, W., Rietbergen, B.V., Lochmüller, E.M., Lill, C.A., Eckstein, F. and Rüegsegger, P. (2002) Estimation of Distal Adius Failure Load with Micro-Finite Element Analysis Models Based on Three-Dimensional Peripheral Uantitative Computed Tomography Images. Bone, 30, 842-848. https://doi.org/10.1016/S8756-3282(02)00736-6

[35] Casagrande, D.J., Morris, R.P., Carayannopoulos, N.L. and Buford, W.L. (2016) Relationship between Ulnar Variance,Cortical Bone Density, and Load to Failure in the Distal Radius at the Typical Site of Fracture Initiation. Journal of Hand Surgery, 41A, 461-468. https://doi.org/10.1016/j.jhsa.2016.08.021

[36] Imade, S., Matsuura, Y., Miyamoto, W., Nishi, H. and Uchido, Y. (2009) Breakage of Volar Locking Compression Late in Distal Radial Fracture. Injury Extra, 40, 77 80. https://doi.org/10.1016/j.injury.2009.01.012

\section{Submit or recommend next manuscript to SCIRP and we will provide best service for you:}

Accepting pre-submission inquiries through Email, Facebook, LinkedIn, Twitter, etc. A wide selection of journals (inclusive of 9 subjects, more than 200 journals)

Providing 24-hour high-quality service

User-friendly online submission system

Fair and swift peer-review system

Efficient typesetting and proofreading procedure

Display of the result of downloads and visits, as well as the number of cited articles

Maximum dissemination of your research work

Submit your manuscript at: http://papersubmission.scirp.org/

Or contactwjet@scirp.org 